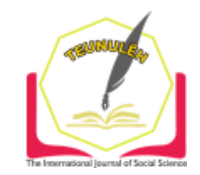

Jurnal Ilmiah Teunuleh

The International Journal of Social Sciences

Vol. 1, Issue. 2, Dec 2020

E-ISSN: 2746-4393

\title{
THE EFFECT OF ORGANIZATIONAL JUSTICE AND CONFLICT MANAGEMENT ON LOYALTY OF VOCATIONAL HIGH SCHOOL TEACHERS IN CENTRAL JAKARTA INDONESIA
}

\author{
Ria Aprilia Fredy ${ }^{1}$ \\ Masduki Ahmad² \\ Heru Santosa ${ }^{3}$ \\ ${ }^{123}$ State University of Jakarta, Indonesia \\ Email: apriliatoding@gmail.com
}

\begin{abstract}
The purpose of this study is to comprehensively describe and describe the effect of organizational justice and conflict management on loyalty of vocational school teachers in central Jakarta Indonesia. This research was conducted to Private Vocational High Schools (SMK) in central Jakarta. Research methods this study uses a quantitative research survey method, as for analyzing data using path analysis. Path analysis technique in this study is to determine the causal relationship between variables or the direct influence of exogenous variables on endogenous variables. Endogenous variables in this study are teachers loyalty, while the exogenous variables in this study are organizational justice and conflict management. Data collection was carried out through questionnaire filling. Based on the calculation results obtained by path analysis 1) the direct effect of organizational justice on teachers loyalty, the value of the path coefficient of 0.425 and $t_{\text {count }}$ of 6.6964 , meaning that organizational justice has a direct positive effect on teachers loyalty can be accepted increasing organizational justice resulting in increased teachers loyalty. 2) The direct effect of conflict management on the teachers loyalty, path coefficient of 0.225 and $t_{\text {count }}$ of 3.378. Means, the direct influence of conflict management on teachers loyalty, the value of the path coefficient of 0.425 and $t_{\text {count }}$ of 6.6964. 3) Organizational justice has a direct positive effect on teachers loyalty can be accepted. That is, increasing organizational justice results in increased teachers loyalty.
\end{abstract}

Keywords: Organizational Justice, Teachers Loyality, Conflict Management 


\section{A. Introduction}

Schools are places to produce the nation's future generations, where in the future they will continue the struggle in developing our nation. Vocational High School is an institution that has a role in creating qualified and competent Human Resources (HR) in their fields. Quality and competent Human Resources (HR) are workers who are ready to face the workforce, and can demonstrate expertise in mastery of science, technology and skills, and are also followed by good morals, ethics and character.

The actors of education in schools of course have a very important role, according to their respective fields, one of which is the teaching staff. The teaching staff has a very important role in educating students, in order to create a quality next generation, qualified teaching staff are also needed, and the loyalty of teaching staff is a determining factor in creating quality teaching staff. Low employee loyalty can result in decreased productivity and employee work discipline. It can also result in an increase in the number of employee turnover.

One of the factors that influence teacher loyalty in an educational organization is organizational justice. A teacher will certainly feel comfortable and be more motivated in carry out their duties and responsibilities if the teacher feels creation of organization justice within an educational institution. Teachers will not only carry out their duties only in terms of responsibility but will carry them out with joy and wholeheartedly. Organizational justice is a concept of balance that is expected to be applied by organizations in treating employees with the aim of triggering a sense of commitment in employees. When employees believe they find injustice at work, they are less likely want to do their job done.

Another factor that affects the loyalty of teaching staff is how well a leader in managing conflicts that occur in an educational institution. It is undeniable that in an organization, conflicts will inevitably occur, both among individuals or between groups. The ability of organizational leaders to carry out conflict management properly here will be very necessary, because it will give its own value to teachers and educators who experience the conflict. Not a few leaders are not wise in resolving conflicts that occur, one of the factors that influence is usually because of the close relationship between a particular teacher and the leader, both familial closeness or emotional closeness. This conflict resolution method makes teachers trust and creates dedication to the school apart from other material matters, because the loyalty of a teacher is not only limited to material fulfillment but also psychological satisfaction of the teacher. 
The Effect of Organizational Justice and Conflict Management...

Like a magnet that strongly attracts metal, this also applies to employees who have the desire to remain in the company and be loyal to the organization they are doing, it is also determined by how well the leadership is in managing the conflict that occurs. Nyoman Mister in his journal says that, (Davis \& Newstorm, 2002) define work commitment as the degree to which employees identify the organization and want to continue participating in the organization's activities. Based on this definition, it can be illustrated that work commitment is the care, loyalty and partiality of employees to the organization they have chosen as well as psychological, emotional, and intellectual attachment by paying attention to the existing organizational culture of an employee to fulfill his promises and carry out his duties and professional obligations both to the organization. Nor the society it serves. (Mister, Rini, \& Karwan, 2017)

Based on the description above, these things can be used as material for consideration of conducting deeper research on the Effects of Organizational Justice and Conflict Management on Loyalty of Vocational High School Teachers in Central Jakarta Indonesia. From this research it is theoretically expected to be a comparison and enrich information about teachers loyalty that is directly affected by Organizational Justice and Conflict Management, reinforcement of existing theories so that they can become a reference within the framework of teachers loyalty. While practically benefiting the Vocational High School in Central Jakarta in developing the duties of the principal, and adding insight to researchers in particular and to the management of education management and to the education observer community.

Guillon and Cezanne (Guillon \& Cezanne, 2014) in his journal expresses his opinion regarding loyalty is: a psychological inclination, a "feeling" such as identification with, attachment or commitment to the organization. This psychological inclination can take an emotional or moral nature and is difficult to observe directly. Researchers and managers generally rely on self-reported, qualitative evaluations to measure it. In some studies, attitudinal loyalty can also be approximated by indicators such as intended absenteeism. Job loyalty will be created when teachers feel fulfilled in fulfilling the necessities of life from the results of their work, so that they feel at home working in one school. Trianasari (Trianasari, 2005), which is quoted Sasmitaningrum (2008) emphasized that the factors that influence employee job loyalty are the existence of work facilities, welfare benefits, work atmosphere and wages received from the company.

Furthermore, (Kusumo, 2006) which is quoted Sasmitaningrum (2008) states that the emergence of job loyalty is influenced by four factors, the four factors are: 1) Personal 
characteristics, including age, years of service, gender, level of education, achievement, race and several personality traits. 2) Job characteristics, in the form of work challenges, job stress, opportunities for social interaction, job enrichment, identification of tasks, feedback on tasks and job compatibility. 3) The characteristics of the company design, related to the internal company, which can be seen from the decentralization, the level of formalization, the level of participation in decision making, at least it has shown various levels of association with corporate responsibility, functional dependence and the control function of the company. 4) Experience gained in work, including a positive attitude towards the company, a sense of trust in a positive attitude towards the company, a sense of security.

Based on the opinion of the experts stated above, it can be synthesized that loyalty is the willingness of employees to give all their abilities, creativity, thoughts and time and the desire to always give their best to achieve company goals. The indicators contained in this loyalty include the obedience of employees in obeying regulations, willingness to cooperate, sense of responsibility, sense of belonging, and loving to work.

T. Akram (2020) in his journal expressed his opinion regarding organizational justice, the concept of organizational justice is based on Equity Theory which is extracted from the concept of justice or fairness. Organizational justice is mainly defined as the employees perceptions about the degree of fairness with which they are treated by organizational authoritie. This opinion suggest that organizational justice is a concept of justice, which is formed from how fairly a leader treats his employees. Perceptions of fairness in an organization have an influence on psychological well-being in the workplace because treating workers fairly and providing appropriate rights, and being respected in a company has a big share in the psychological well-being and productivity that individuals feel comfortable when doing their work. Another opinion from Cropanzano \& Molina (2015) they said: When workers believe that they have been treated justly, they tend to show higher job performance, better work attitudes, and lower levels of stress. The opinion above suggests that the performance of an employee will increase if treated fairly by their leaders, not only work power increase, but also better attitudes and behavior will be shown by employees, this also has an impact on lower stress levels.

According to Mantelli, Stimmler and Roberts (Organizational behavior, 2017) Organizational behavior is about study of how people join together to accomplish tasks toward a common goal. At the individual and group levels, research focuses on the consequences of interpersonal dynamics. At the organizational and industry levels, 
The Effect of Organizational Justice and Conflict Management...

research focuses on strategy, structure, and resource management. The modern history of organizational behavior derives from seminal work on authority and coordination, concerns about human relations, studies of time-motion in workers, and the function of administration. From some of the opinions above, it can be synthesized that what is meant by organizational justice is a condition in which the results obtained by employees are equal to accordance with the work given, and receive equal treatment with all employees in accordance applicable regulations, without any partiality from superiors. The indicators of organizational justice are appropriateness of treatment, equality in the distribution of tasks, then indicators include respect for decision making, and consistency, treatment of leaders towards employees with respect and dignity.

Thakore (2013) expressed his opinion on conflict management in his journal, Inorder to maintain that conflict management, we should have a wide application, and it goes on to state that the significant feature of conflict management is that it is an attempt by the status quo to manage the dispute, or to avoid escalation of the conflict. The conflict resolution also refers to dealing with and conflict management removing the cause of the conflict, and conflict management will refer to both strategies and approaches of containing (managing the conflict) as well as to strategies and approaches of resolving it. Conflict management has at least three stages as follows: First; conflict analysis planning. This stage is the stage of identification of the conflict that occurs, to determine the source of the causes and the parties involved. Conflicts that are already in the open stage are easy to identify, but if they are still in the potential stage, they require a stimulus to be open and recognizable.

Second; conflict assessment. This stage is carried out to determine the conditions of the conflict and its resolution. Whether the conflict has approached a critical point, and needs to be suppressed not to have a negative impact, is it still at the point of having a positive impact, or is it just at a hidden stage, so it is necessary to provide stimulation so that it can approach a critical point and have a positive impact. Third; conflict resolution. This stage is an action for conflict resolution, including providing a stimulus if it is still in a hidden stage and needs to be opened, Mulyasa (2012). The principal as a leader must be active and can be the main party in resolving conflicts that occur in the school environment. Leaders' skills in managing and controlling conflicts that occur are highly dependent on how well the leadership in managing conflict management. To be able to resolve conflicts, it is necessary to understand the causes and sources so that they can be resolved properly and appropriately. Kreitner and Kinicki (1995) adopt five styles 
of conflict handling, namely integrating (problem solving), obliging (smoothing), dominating (forcing), avoiding, compromising.

Nwobodo (2020) wrote his opinion after conducting research on conflict management, the inevitability of conflicts in organization makes the good grasp of the requisite skills/techniques analyzed in the review a key indicator for successful managerial role in any organization. This in turn will boost employee morale and enhance performance which will ultimately translate to improved organizational efficiency. It behooves on all managers, leaders and executives to create structures and policies that will take cognizance of the primacy of conflict competence in successful leadership. The opinion above suggests that conflicts can be managed properly by the leadership to increased skills and will spur the moral quality and performance of employees.

Good conflict handling by the leader will create a good structure in an organization, and show the competence of a leader. Based on the description of the opinion above can be synthesized that conflict management is the ability of leaders to recognize conflicts and manage conflicts that exist within an organization so that they can be used for the common interest. The indicators of conflict management itself are conflict analysis planning, conflict assessment, conflict solving, integrating (problem solving), obliging (smoothing), dominating (forcing), avoiding, and compromising.

\section{B. Method}

This study aims to prove the Effects of Organizational Justice and Conflict Management on Loyalty of Vocational High School Teachers in Central Jakarta Indonesia. While specifically, this study aims to find out empirical information about the influence between exogenous and endogenous variables that exist namely Organizational Justice, Conflict Management and Loyalty. To analyze the relationship between variables used path analysis, while the relationship between variables analyzed is formed as shown below:

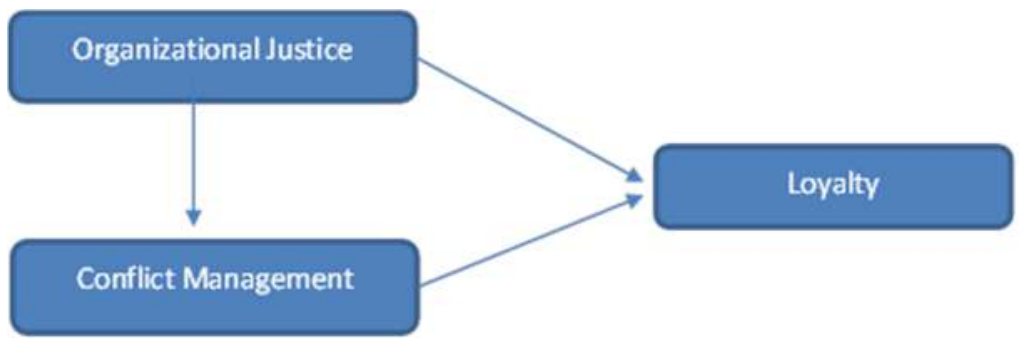

$\mathrm{H}_{1}$ : Positive direct effect of the organizational justice on loyalty of vocational high school 
The Effect of Organizational Justice and Conflict Management...

teachers in central Jakarta.

$\mathrm{H}_{2}$ : Positive direct effect of the conflict management on loyalty of vocational high school teachers in central Jakarta.

$\mathrm{H}_{3}$ : Positive direct effect of the organizational justice on conflict management of vocational high school teachers in central Jakarta.

The sample in this study amounted to 310 teachers, which were obtained using the Slovin formula and random sampling from 1392 teachers population of Vocational High Schools in Central Jakarta. The data collection technique is by distributing questionnaires containing questions to each respondent who is a research sample.

\section{Research and Discussion Results}

The condition for path analysis is the estimation of the relationship between variables that are linear, and this also applies to the regression analysis. Other requirements that must be met are that the study sample must originate from a normally distributed population, and the influence between variables in the model must be significant and linear. Before testing the model, the normality test, significance test and linearity coefficient of regression coefficients are first performed.

Normality test is performed using the Liliefors Test technique, with the test criteria, Data is normally distributed, if the value of $L_{\text {count }} \leq$ of the value of $L_{\text {table, }} \mathrm{Hi}$ : Data is not normally distributed, if the value of $L_{\text {count }}>$ of the value of $L_{\text {table. }}$. Ho rejection limits are listed in the Liliefors table with a significant level $\alpha=0.05$ and $n=310$ obtained L0 table of 0.061 . Based on the results of the estimated error normality tests between variables can be seen in the following table:

Table 1. Test Results for Estimated Error Normality Between Variables

\begin{tabular}{|c|l|c|c|c|c|}
\hline \multirow{2}{*}{ No. } & \multirow{2}{*}{ Variable } & \multirow{2}{*}{$L_{\text {count }}$} & \multicolumn{2}{|c|}{$L_{\text {table }}$} & \multirow{2}{*}{ information } \\
\cline { 4 - 5 } & & & $\alpha=0.05$ & $\alpha=0.01$ & \\
\hline 1 & $X_{3}$ on $X_{1}$ & 0.060 & 0.061 & 0.071 & Normal \\
\hline 2 & $X_{3}$ on $X_{2}$ & 0.052 & 0.061 & 0.071 & Normal \\
\hline 3 & $X_{2}$ on $X_{1}$ & 0.038 & 0.061 & 0.071 & Normal \\
\hline
\end{tabular}

By looking at the table above it can be concluded that all data pairs both loyalty to organizational justice, loyalty to conflict management, and conflict management to organizational justice come from populations that are normally distributed. To test the hypothesis of influence and relationships between variables, regression and correlation 
Ria Aprilia Fredy, Masduki Ahmad, Heru Santosa

analysis techniques are used. Based on the test results of the significance and linearity of the regression between variables can be seen in the table below:

Table 2. Results of Significance Tests and Regression Linearity Tests

\begin{tabular}{|c|c|c|c|c|c|}
\hline \multirow{2}{*}{ No } & \multirow{2}{*}{ Variable } & \multicolumn{2}{|c|}{ Significance } & \multicolumn{2}{c|}{ Liniearity } \\
\cline { 3 - 6 } & & $F$ count & $F_{\text {able }(\alpha=0,01)}$ & $F$ count & $\begin{array}{c}F_{\text {able }} \\
(\alpha=0.05)\end{array}$ \\
\hline 1 & $X_{3}$ on $X_{1}$ & 4.6599 & 3.874 & 1.117 & 1.39 \\
\hline 2 & $X_{2}$ on $X_{1}$ & 9.7337 & 3.874 & 0.9958 & 1.39 \\
\hline 3 & $X_{3}$ on $X_{2}$ & 5.019 & 4.706 & 1.068 & 1.395 \\
\hline
\end{tabular}

Meanwhile based on the calculation of the correlation between variables can be seen in the table below:

Table 3. Simple Correlation Coefficient Matrices between Variables

\begin{tabular}{|c|l|l|l|}
\hline \multirow{2}{*}{ Matrices } & \multicolumn{3}{|c|}{ Correlation Coefficient } \\
\cline { 2 - 4 } & $\mathrm{X}_{1}$ & $\mathrm{X}_{2}$ & $\mathrm{X}_{3}$ \\
\hline $\mathrm{X}_{1}$ & 1 & 0.225 & 0443 \\
\hline $\mathrm{X}_{2}$ & 0.225 & 1 & 0.261 \\
\hline $\mathrm{X}_{3}$ & 0.443 & 0.261 & 1 \\
\hline
\end{tabular}

From the above table it can be concluded that the correlation between organizational justice and conflict management is 0.225 . The correlation between organizational justice and loyalty is 0.443 . The correlation between conflict management with loyalty is 0.261 . Based on table, the results of the calculation of the path analysis effect of organizational justice on loyalty:

Table 4. Path coefficients Effect of X1 to X3.

\begin{tabular}{|c|c|c|c|c|}
\hline \multirow{2}{*}{ Direct Positive Effect } & Path coefficients & $t_{\text {count }}$ & \multicolumn{2}{|c|}{$t_{\text {table }}$} \\
\cline { 4 - 5 } & & & $\alpha=0.05$ & $\alpha=0.01$ \\
\hline$X_{1}$ to $X_{3}$ & 0.425 & $6.6964^{* *}$ & 1.971 & 2598 \\
\hline
\end{tabular}

${ }^{* *}$ ) the path coefficient is very significant (6.6964> 2.598 at $\alpha=0.01$ )

The path coefficient value is 0.425 and the tcount is 6.6964. The value of $t_{\text {table }}$ for $\alpha=0.01$ is 2.598 , because the value of $\mathrm{t}$ is more than $\mathrm{t}$ table then $\mathrm{HO}$ is rejected and $\mathrm{Ha}$ is accepted, thus the organizational justice has a direct positive effect on loyalty can be accepted. Thus it can be concluded that improved organizational justice results in 
The Effect of Organizational Justice and Conflict Management...

increased loyalty.

The results of this study are consistent with the results of research conducted by Sutrisno (2012) states that the Theory of Justice states that every human being always wants justice as a driving force that motivates them to work so that they get satisfaction from the job they have. And Johns (2001) Equity theory explains that employees will reduce the amount of their contribution after they feel they are treated unfairly. Workers are likely to react by starting to arrive late, moving on to more serious measures, such as being absent and finally deciding to leave. (Indrayani \& Suwandana, 2016)

In table 5 . The results of the calculation of the path analysis influence the conflict management on loyalty:

Table 5. Path coefficients Effect of X2 on X3

\begin{tabular}{|c|c|c|c|c|}
\hline \multirow{2}{*}{ Direct Positive Effect } & \multirow{2}{*}{ Path Coefficients } & \multirow{2}{*}{$t_{\text {count }}$} & \multicolumn{2}{|c|}{$t_{\text {table }}$} \\
\cline { 3 - 5 } & & & $\alpha=0.05$ & $\alpha=0.01$ \\
\hline$X_{2}$ to $X_{3}$ & 0.178 & $2.811^{* *}$ & 1.971 & 2.598 \\
\hline
\end{tabular}

$\left.{ }^{* *}\right)$ significant path coefficient $(2.811>2.598$ at $\alpha=0.01)$

The path coefficient value is 0.178 and tcount is 2.811 . The value of table for $\alpha=$ 0.01 was 2.598. Because tcount is more than ttable, $\mathrm{HO}$ is rejected and $\mathrm{Ha}$ is accepted, thus the conflict management has a direct positive effect on loyalty. Thus it can be concluded that increasing the conflict management results in increased loyalty.

The results of this study are consistent with the results of research conducted by Anaroga (1992) he said: best conflict management is by minimizing the negative consequences of conflict is one way of increasing work loyalty. Job loyalty is a condition and activity involving physical, psychological and social issues that cause individuals to have a strong sense of belonging, willingness to cooperate, have an attitude to obey, personal identification of work and company, there is an effort to implement and maintain regulations with full awareness and responsibility and willingness to contribute an efforts to achieve the goals of the company organization in accordance with their expertise so create an increase in organizational effectiveness and with strong dedication. Loyalty is the desire of a person to provide ability, dedication, identify and feel that he is part of an organization shown by the desire to work and try his best and to maintain his membership in that organization and help realize the goals of the organization (Steers, 1984).

In table 6 . The results of the calculation of the path analysis influence the 
Ria Aprilia Fredy, Masduki Ahmad, Heru Santosa

organizational justice of the conflict management

Table 6. Path coefficients Effect of X1 to X2

\begin{tabular}{|c|c|c|c|c|}
\hline \multirow{2}{*}{ Direct Positive Effect } & \multirow{2}{*}{ Path Coefficients } & \multirow{2}{*}{$t_{\text {count }}$} & \multicolumn{2}{|c|}{$T_{\text {table }}$} \\
\cline { 3 - 5 } & & & $\alpha=0.05$ & $\alpha=0.01$ \\
\hline$X_{1}$ to $X_{2}$ & 0.225 & $3.378^{* *}$ & 1.971 & 2598 \\
\hline
\end{tabular}

**) significant path coefficient (3.378> 2.598 at $\alpha=0.01)$

Path coefficient value of 0.225 and tcount of 3.378. The value of $t_{\text {table }}$ for $\alpha=0.01$ was 2.598. Because the value of $\mathrm{t}$ is greater than table then $\mathrm{HO}$ is rejected and $\mathrm{Ha}$ is accepted, thus the positive direct effect of organizational justice on the conflict management can be accepted. Thus it can be concluded that improved organizational justice results in an increase in the conflict management.

These findings are in line with the results of Komlemyer and Parker (2012) Organizational justice has an impact on employee performance, where organizational justice can play an important role in determining employee attitudes and behavior which in this case who suggest that the perception of unfair behavior from the organization to employees can reduce mentality, movement, even in some cases within the organization. This shows that organizational justice can be used as a form of employee evaluation of the behavior carried out by the organization towards its employees.

Organizational fairness can increase employee productivity and performance, this shows that when managers behave fairly with employees, a positive relationship will be formed between them. This positive relationship will lead to motivation and will increase professional performance. In other words, organizations that apply good organizational justice will motivate their employees to improve their performance and can have good mental health due to positive relationships so as to reduce stress level.

\section{Conclusions}

Based on the research results, it can be concluded that organizational justice has a direct positive effect on the loyalty, the conflict management has a direct positive effect on loyalty, and organizational justice has a direct positive effect on the conflict management. This means that if the school wants to increase the teachers loyalty, then the school needs to create and provide a good organizational justice and conflict management. In addition, the creation of good organizational justice can improve the conflict management for teachers. Based on the implications of the research that has 
The Effect of Organizational Justice and Conflict Management...

been described, it is recommended that school principals as leaders provide a lot of encouragement by improving communication, giving attention and support to educators in facing obstacles and challenges inside or outside the school so that educators can increase teachers loyalty in school organizations.

The research implications for improving organizational justice and improving the conflict management in order to improve the teachers loyalty in schools are as follows: 1) Suggestions for school principals. Principals as leaders in Vocational High Schools are expected to provide more encouragement by increasing communication, giving attention and support to educators in facing obstacles and challenges inside or outside the school so that teaching staff can increase commitment in school organizations. 2) Suggestions for educators. Educators should be able to manage and maintain a good work environment within the school so that it can provide comfort for other educators, and can have a positive influence on students, others and even the school. 3) Suggestions for future researchers. There are still many other factors that affect the affective commitment of educators that have not been answered through this research such as motivational factors, incentives, welfare levels, organizational culture, etc. which can be explained through further research.

\section{Bibliography}

Al-Zu'bi, H. A. (2010). A Study of Relationship between Organizational Justice and Job Satisfaction. International Journal of Business and Management.

Arif, M. (2013). Hubungan Kepemimpinan Situasional Kepala Sekolah, Dukungan Keluarga, dan Pengembangan Karier Guru dengan Loyalitas Guru SMP Swasta di Kecamatan Sunggal Kabupaten Deli Serdang. Journal of Petrology.

Cropanzano, R., \& Molina, A. (2015). Organizational Justice. International Encyclopedia of the Social \& Behavioral Sciences(2). doi:10.1016/B978-0-08-097086-8.22033-3

Guillon, O., \& Cezanne, C. (2014). Employee loyalty and organizational performance: A critical survey. Journal of Organizational Change Management. doi:10.1108/JOCM-02-2014-0025

Indrayani, L. P., \& Suwandana, I. G. (2016). Pengaruh Keadilan Organisasional Terhadap Kepuasan Kerja Dan Komitmen Organisasional Pada Karyawan. E-Jurnal Manajemen, 5(6), 3589-3619.

Martelli, P. F., Stimmler, M. K., \& Roberts, K. H. (2017). Organizational behavior. Neuroscience and Biobehavioral Psychology. doi:10.1016/B978-0-12-8093245.06506-8 
Nihayawati, N. (2017). Hubungan Antara iklim organisasi dengan keadilan organisasi pada karyawan di Kantor Pusat PDAM Tirta Wijaya Cilacap. Jurnal Psikologi, 8-28.

Nurhayat, C. E., \& Mithat, K. (2016). Teachers loyalty to their supervisors and organizational commitment. Educational Research and Reviews, 11(12), 11611167. doi:10.5897/err2016.2808

Nwobodo, A. E. (2020). Running head: Managing Conflict and Negotiating. 1-17.

Nyoman, M., Riswanti, R., \& Karwan, D. (2017). Pengaruh Efektivitas Komunikasi, Manajemen Konflik Kepala Sekolah Dan Komitmen Kerja Guru Terhadap Disiplin Kerja Guru Di Sekolah Menengah Kejuruan Kalianda. ABA Journal, 102(4), 24-25. doi:10.1002/ejsp.2570

Tayyaba, A., Shen, L. H., \& Muhammad, J. H. (2020). The Impact of Organizational Justice on Employee Innovative Work Behavior. Mediating role of knowledge.

Thakore, D. (2013). Contract and conflict management. Journal of Business and Management, 8(3), 7-16.

Wibiesono, S. (2009). Analisis Loyalitas Karyawan Melalui Program Pemeliharaan Karyawan PT X Tbk (Unit Bisnis Bogor). Bogor: IPB University. 